\title{
NeW Approach to LiVE Body MASS ESTIMATION
}

\author{
BRUS, M.; JANZEKOVIC, M.; VINDIS, P.; \\ MURSEC, B. \& STAJNKO, D.
}

Abstract: For establishing the body mass of live animals it is possible to use various mechanical, digital and video devices. The experimental group of 30 bulls was measured five times every 60 days from housing at the average age of 139 days (181 $\mathrm{kg}$ ) till slaughtering (449 days, $594 \mathrm{~kg}$ ). During experiment the bulls were weighed by electronic weighing device EC 2000, the trunk length (d) and the chest size (o) were measured simultaneously and captured by the thermal camera. The results showed that the calculation is very accurate within certain body mass, when the animal's frame is of rectangular shape and the body structure in the front and the rear part is almost equally deep. For image analysis at different ages also two linear models for estimating current body weight were developed on the basis of the long term herd data. Therefore the thermal camera shows to be a useful tool among all.

Key words: bull, body dimensions, thermography, weight
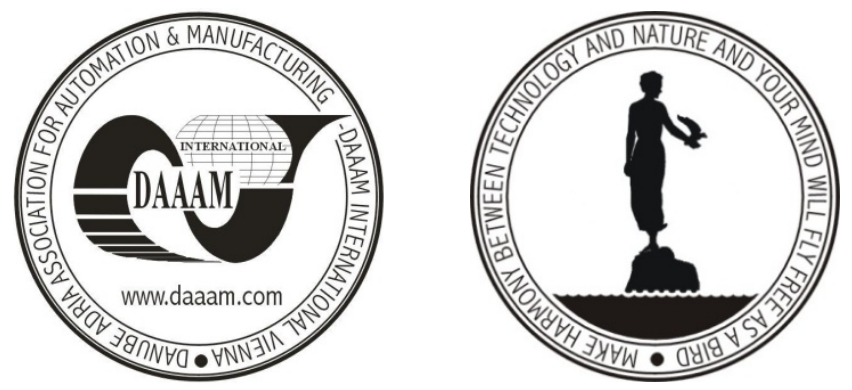

Authors' data: $\mathrm{PhD}$. Brus, M[aksimiljan]; Ass. Prof. Janzekovic, M[arjan]; PhD. Vindis, P[eter]; Prof. Dr. Mursec, B[ogomir]; Ass. Prof. Stajnko, D[enis],University of Maribor, Faculty of Agriculture, Vrbanska cesta 30, 2000 Maribor, Slovenia, maksimiljan.brus@uni-mb.si,marjan.janzekovic@uni-mb.si,peter.vindis@uni-mb.si, bogomir.mursec@uni-mb.si,denis.stajnko@uni-mb.si

This Publication has to be referred as: Brus, M[aksimiljan]; Janzekovic, M[arjan]; Vindis, P[eter]; Mursec, B[ogomir] \& Stajnko, D[enis] (2008). New Approach to Live Body Mass Estimation, Chapter 14 in DAAAM International Scientific Book 2008, pp. 161-170, B. Katalinic (Ed.), Published by DAAAM International, ISBN 978-3-901509-66-7, ISSN 1726-9687, Vienna, Austria

DOI: $10.2507 /$ daaam.scibook.2008.14 